\title{
Kunstnerisk vilje i spennet mellom resonans og dissonans
}

\section{Ledelse $i$ danseimprovisasjon som scenekunstpraksis}

\author{
Hilde Rustad* \\ Norges Idrettshøyskole
}

\begin{abstract}
Sammendrag
Denne artikkelen handler om hvordan det å jobbe med danseimprovisasjon som scenekunst gjøres. Kunstnerisk vilje er et sentralt omdreiningspunkt for artikkelen. Med utgangspunkt i en forestilling fra 2009 undersøker jeg retrospektivt, selvkritisk og refleksivt kunstmateriale og erfaringer knyttet til ledelse og kunstneriske viljer uttrykt i danseimprovisasjon som scenekunst. Gjennom kritisk å undersøke det å forske på kunst med kunst bidrar artikkelen med kunnskap om danseimprovisasjon som scenekunstpraksis, hvor aktiv sammenhet og dialogiske ferdigheter står sentralt. Gjennom et Bakhtinsk polyfont perspektiv, og ved å "lytte til" resonans og dissonans, belyser artikkelen hvilke roller metoder og lederskap kan spille i scenekunstpraksiser, samt hvordan improvisasjon og improvisasjonsutøveren kan forstås. Artikkelen setter spørsmålstegn ved etablerte konvensjoner i dansekunstfeltet og synliggiør problematiske forhold ved dobbeltrollen som prosjektleder og utøver, en dobbeltrolle som er vanlig i norsk samtidsdans.
\end{abstract}

\section{Nøkkelord: Kunstarbeidsprosesser; improvisasjon; koreografi; lederskap; Bakhtin}

\begin{abstract}
This article is concerned with dance improvisation as performance practice. The dominant theme is artistic intent. The author retrospectively, self-critically and reflexively examines a project staged in 2009, scrutinizing its artistic material and experiences gained in the process from the perspective of leadership and artistic intent. Based on a critical examination of how to do artistic research, and by examining and analyzing one specific performing arts process, the article contributes new knowledge on dance improvisation as a performing art in which active togetherness and dialogical skills play an important part. It also illuminates the role of methods and leadership in performing arts processes, and shows how improvisation and improvisers as well as resonance and dissonance related to artistic intent can be understood in a polyphonic Bakhtinian perspective. Finally, the article questions existing conventions and problematizes the dual role of leader and dancer commonly found in Norwegian contemporary dance.
\end{abstract}

^Korrespondanse: Hilde Rustad, Seksjon for kroppsøving og pedagogikk, Norges idrettshøgskole, Postboks 4014 Ullevål stadion, 0806 Oslo. Epost: hilde.rustad@nih.no

(C) 2018 H. Rustad. This is an Open Access article distributed under the terms of the Creative Commons Attribution 4.0 International License (http://creativecommons.org/licenses/by/4.0/), allowing third parties to copy and redistribute the material in any medium or format and to remix, transform, and build upon the material for any purpose, even commercially, provided the original work is properly cited and states its license.

Citation: H. Rustad. "Kunstnerisk vilje $i$ spennet mellom resonans og dissonans - Ledelse $i$ danseimprovisasjon som scenekunstpraksis". Fournal for Research in Arts and Sports Education, Special Issue: "Å forske med kunsten» Vol. 2, 2018, 
Keywords: Performing arts processes; improvisation; choreography; leadership roles; Bakhtin

Received: May, 2017; Accepted: February, 2018; Published: March, 2018.

Som forsker og dansekunstner er jeg opptatt av hvordan det å jobbe med danseimprovisasjon som gruppe giøres. Hvordan planlegges, gjennomføres og erfares scenekunstneriske danseimprovisasjonsprosjekter der dansekunstnere og andre kunstnere deltar? I denne artikkelen undersøker jeg det å lede et scenekunstdanseimprovisasjonsprosjekt gjennom å se på enkelthendelser som fant sted i tilknytning til prosessen med en forestilling, som ble spilt i 2009. Hensikten er å forske på kunst med kunst for å bidra til kunnskap om danseimprovisasjon som scenekunst. Kunnskapsbidraget omfatter ledelse, metoder og prosesser, og et viktig tema som synliggiøres, er dobbeltrollen som prosjektleder og utøver. Artikkelens omdreiningspunkt er «kunstnerisk vilje», som inngår i artikkelens problemstilling: På hvilke måter kommer kunstnerisk vilje til syne $i$ en arbeidsprosess med danseimprovisasjon som scenekunst? Formuleringen «kunstnerisk vilje» er hentet fra Bakhtin (2003) og handler om «viljen til å føre sammen mange viljer» (s. 161). I artikkelen forstås «kunstnerisk vilje» i tillegg som knyttet til kunstneriske ideer, intensjoner og gjennomføringsevne. Arbeidsprosess brukes som et samlebegrep som favner både prøveperiode og forestillinger.

\section{Arbeidsprosess-skisse}

Forestillingen var et scenekunstimprovisasjonsprosjekt hvor arbeidsprosessen bestod av fem ukers prøvetid og fire forestillinger. Vi var åtte utøvere, fem dansekunstnere, en musiker/komponist, en billed-/filmkunstner og en lysdesigner. Dansekunstnerne arbeidet hele prøveperioden, mens de andre tre var med i perioder. Jeg var initiativtager og leder for prosjektet, og valg av utøvere falt på nettopp disse fordi jeg hadde arbeidet med dem tidligere eller sett dem på scenen. Lysdesigneren, som jeg ikke kjente til fra før, ble anbefalt av en lysdesigner jeg stolte på. Alle utøverne hadde improvisasjonskompetanse, og alle arbeidet med improvisasion i arbeidsprosessen.

I prøveperioden var daglig rutine at danserne byttet på å lede oppvarmingen, hvorpå vi arbeidet med improvisasjon, ofte ved å gjennomføre tidsavgrensede improvisasjoner. Deretter snakket vi sammen om improvisasjonen vi nettopp hadde giennomført. Vi byttet på å sitte utenfor som et «ytre øye», da det tidlig ble klart at vi arbeidet betydelig bedre når en av oss satt utenfor, enn når alle deltok. De som improviserte, kunne dermed rette handlinger mot flere og ha relasjoner både til hverandre og til tilskueren, som kunne fortelle hva hun hadde sett og tenkt. Denne måten å arbeide på utgjorde en dialogisk metode som bidro til at vi fikk bedre forståelse av hva vi holdt på med, og gjennom at vi satte ord på det vi hadde sett, opplevd og erfart, fikk vi økt bevissthet rundt det som skjedde; det handlet om å utforske improvisasjon som scenekunstuttrykk. Vi vekslet mellom å improvisere og snakke, og om dette skriver Leena Rouhiainen (2008) at «this immediate dialogue can lead to 


\section{H. Rustad}

forming an understanding of the improvisatory event» (s. 55). Nettopp det at samtalen fulgte umiddelbart etter improvisasjonen, muliggjorde en felles forståelse av det vi holdt på med. Det at en av oss så på, ga improvisasjonen relasjonell mening ved at utøverne kunne rette improvisasjonshandlinger mot en tilskuer. Gjennom denne metoden utviklet vi et felles språk for improvisasjon som prosess og erfaring, samtidig som vi gjennom praksis videreutviklet oss som improvisasjonskunstnere både individuelt og som kollektiv.

Ulempen ved å jobbe med et «ytre øye» var at ikke alle deltok i improvisasjonene, og at vi i prøveperioden ofte improviserte med færre utøvere enn i forestillingene. I periodene da musikeren, billed-/filmkunstneren og lysdesigneren var til stede, byttet alle åtte utøverne på å inneha rollen som ytre øye, og alle deltok daglig i fysisk oppvarming. Å jobbe kollektivt på denne måten bidro til et ikke-hierarkisk arbeidsmiljø hvor min opplevelse var at alle var tilnærmet likestilt, og hvor jeg som leder var "centrally engaged in 'meaning making' for their [our, my addition] audiences or followers» (Ladkin \& Taylor, 2010, s. 238).

Vi jobbet med «åpen» eller «ustrukturert» improvisasjon, men med en forhåndsbestemt tidsramme. Når det nærmet seg forestillingene, jobbet vi i økende grad med improvisasjoner hvor alle var med, og som om det var forestilling.

\section{Kunstnerisk forskning som selvstudieforskning}

Som kunstnerisk forskning handler artikkelen om at jeg, som kunstner og forsker, undersøker danseimprovisasjon som scenekunstpraksis gjennom arbeidsprosessen knyttet til forestillingen. Rouhiainen (2008) ser det som en styrke å utvikle kunnskap knyttet til spesifikke praksiser og foreslår at kunstnerisk forskning, som hun forstår som kroppsliggjort sosial og kontekstuell, kan si noe om, eller fornye, sosiale relasjoner samt sette spørsmålstegn ved etablerte kulturelle konvensjoner og normer. Hun skriver at kunstnerisk forskning $i k k e$ framskaffer "cumulative knowledge adding to a universally shared truth", men heller "partial 'knowledges' related to the local and particularized practices artists construct their experiences, understandings and conceptions through" (Rouhiainen, 2008, s. 52).

Forskningsprosjektet er retrospektivt og handler i hovedsak om å fortolke min erfaring, som ligger nær ni år tilbake i tid. Det anvendte forskningsperspektivet er fortolkende (Borgdorff, 2006, s. 11) og hører inn under et hermeneutisk og fenomenologisk forskningsparadigme.

Jeg forstår erfaringene som autobiografisk materiale og selve forskningsprosjektet som en selvstudie (Bullough \& Pinnegar, 2001). «Verdien i en selvstudie er at den kan bidra til å forstå, synliggjøre, utfordre og provosere til endring», skriver Bullough og Pinnegar (s. 137). Selvstudier konsentrerer seg alltid om praksis og om «the space between the self and the practice engaged in" (Bullough \& Pinnegar, 2001, s. 15). De skriver videre at det alltid er en spenning mellom en selv og praksisfeltet og mellom forskerens relasjon til praksis og forskerens relasjon til utøverne man deler praksis med (Bullough \& Pinnear, 2001, s. 15). 
Robert Bullough og Stefinee Pinnegar (2001) hevder at hvem forskeren er, er sentralt for hva forskeren gjør (s. 13), og de er opptatt av at kvalitet i selvstudieforskning krever at forskeren forhandler en sensitiv balanse mellom biografi og historie (s. 15). Jeg vil derfor kort situere meg selv: Jeg er utdannet danser og koreograf ved School for New Dance Development ${ }^{1}$, som i min studentperiode var sterkt preget av amerikansk postmoderne dans. Jeg har omfattende erfaring fra danseimprovisasjon, ${ }^{2}$ kontaktimprovisasjon og koreografi som utøver, koreograf og kunstnerisk leder i det profesjonelle dansekunstfeltet. Som forsker har jeg ved flere anledninger skrevet om improvisasjon (Rustad, 2013, 2010a, 2010b).

Jeg forholder meg til kunstnerisk forskning som selvstudieforskning. Aslaug Nyrnes (2006, s. 14) beskriver kunstnerisk forskning som en aktivitet der forskeren beveger seg mellom tre topoi: (a) kunstmaterialet, (b) det egne språket og (c) teorien. Jeg følger Nyrnes og beveger meg rundt i dette topologiske landskapet hvor "prosessen handler om å utforske forhold, balanse, bevegelser og progresjon mellom de tre forskningsområdene» (Nyrnes 2006, s. 18, min oversettelse fra engelsk). Jeg starter med teorien og vender senere tilbake til kunstmaterialet.

\section{Teorien: Bakhtins begrep}

Slik jeg forstår Nyrnes, er teori et systematisk språk som har å gjøre med sammenlignende perspektiv og som inneholder klart definerte begrep. Teori er avhengig av kategorisering, og å kategorisere handler om å se etter likheter og forskjeller (Nyrnes, 2006, s. 16). Jeg har valgt å anvende den russiske litteraturviteren og filosofen Mikhail Bakhtins (1885-1975) teorier, og særlig hans begrep dialog, ytring, stemme, polyfoni og heteroglott, for bedre å forstå og sette ord på erfaringer knyttet til danseimprovisasjon som scenekunstpraksis.

Dialog er for Bakhtin et hovedbegrep, og han hevder at alle former for kommunikasjon er basert på dialogiske relasjoner mellom selvstendige ytringer, selvstendige subjekter, og mellom «jeg» og «du» (Børtnes, 2008, s. 98). Det kan dreie seg om både «ytre dialog» og «indre dialog»; ytre dialog er fortrinnsvis dialog mellom personer, mens indre dialog kan være for eksempel dialog mellom tidligere erfaringer og det som skjer her og nå. Indre dialog kan forstås som dialog mellom utøveren og improvisasjonen selv.

Bakhtin hevder at språket er "dialogisk», og at en «ytring» er den mest sentrale språkenheten til rådighet i kommunikasjon (Igland \& Dysthe, 2008, s. 108). De som ytrer seg, er "stemmer». En «ytring» er aldri isolert, men inngår i en dialog (Bakhtin, 2003, s. 12). Jeg anvender begrepet ytring her om en bevegelseshandling i

\footnotetext{
${ }^{1}$ En avdeling ved kunsthøgskolen i Amsterdam.

${ }^{2}$ Jeg har blant annet vært del av Prosjekt Impro (1992-2000), som i tillegg til meg bestod av Bibbi Winberg, Katrine Kirsebom og Camilla Grønneberg (tidlig på 1990-tallet også Steffi Lund og Torhild Jahren), og Impro Ensemble, som foruten meg bestod av Bibbi Winberg, Siri Jøntvedt, Gisle Hass, Irene Velten Rothmund, Katrine Kirsebom og Thomas Gundersen.
} 


\section{H. Rustad}

danseimprovisasjon, mens stemme er en utøver i betydningen danser, musiker, lysdesigner eller billedkunstner, det vil si alle som var involvert i arbeidsprosessen. I gruppeimprovisasjon er utøvere alltid i dialog med andres tilstedeværelse og handlinger og tar valg i relasjon til disse. På denne måten foregår det en konstant interaksjon av meninger i improvisasjonen på lignende vis som i en samtale.

Begrepet heteroglott er knyttet til ytringens kontekstavhengighet. Improvisasjonshandlinger skjer her og nå, valg av handling er tids- og stedsavhengig og skjer først i handlingsøyeblikket. For Bakhtin bærer ordet med seg stemmer fra tidligere brukere, og ytringen blir derfor et møtested for samspill og konfrontasjon mellom talende personligheter med ulike verdiposisjoner (Igland \& Dysthe, 2008, s. 111). Dette betyr at det er nødvendig å se på konteksten ytringen står i, "[the utterance] which will affect the other, how it will do so and in what degree is what is actually settled at the moment of utterance", skriver Bakhtin (1981, s. 426). Heteroglott forstås også som å romme konfliktfylt sameksistens (Rustad, 2013, s. 142) og motsetning og meningsbrytning (Mørch, 2003, s. 19).

Polyfoni står for flerstemmighet. Som litteraturviter oppfattet Bakhtin Dostojevskijs romankarakterer som selvstendige subjekter med egne stemmer, uavhengige av forfatteren. Han hevdet at karakterene ellers i litteraturen oftest talte med forfatterens stemme.

Ved å anvende Bakhtin-begrepene i sammenlignende perspektiv og fortolke og tydeliggjøre kunstmaterialet kan man si noe om hvordan utøvere og uttrykk, som stemmer og improvisasjonsforestilling, står i dialogiske forhold, og hvorvidt arbeidsprosessen er preget av resonans eller dissonans, som at den gir gjenklang eller skurrer (Igland \& Dysthe, 2008, s. 111). Bakhtins interesse ligger i menneskers handling og interaksjon (Stensæth, 2008, s. 187), og jeg forstår begrepene som potente i en meningsfull fortolkning av kunstmaterialet. Andre som har anvendt Bakhtin i kunstrelatert forskning, er Henriette Thune (2012), som bruker Bakhtins teorier som analytisk ramme for estetisk analyse, og Karette Stensæth (2008, 2017), som har Bakhtins teorier sentralt i sin forskning på musikkterapiimprovisasjon.

\section{Kunstmaterialet, det egne språket, beskrivelse og fortolkning}

Det egne språket, verbalspråket, kan være poetisk, fortellende og argumenterende, og ved å beskrive, fortolke og skrive om kunstmaterialet setter jeg kunsten inn i en akademisk, kunnskapsproduserende kontekst (Hovik, 2012, s. 107). Det å skrive om kunstmaterialet innebærer refleksjon og fortolkning, og Nyrnes (2006) understreker betydningen av at forfatteren har størst mulig bevissthet om sitt eget språk (s. 15).

Kunstmaterialet er generert gjennom arbeidsprosessen med forestillingen og utgjøres av Arbeidsprosess-skisse, som er presentert tidligere i artikkelen, og to erfaringsbeskrivelser kalt hendelsen skift og hendelsen bemerkning, som presenteres senere. Arbeidsprosess-skisse gir et innblikk i selve forestillingsprosjektet, og jeg trekker fram hendelsene fordi de står sentralt i min erfaring og derved utgjør en forgrunn mot, i 
fenomenologisk forskningstradisjon (van Manen, 1990), min samlede erfaringsbakgrunn. Det er et poeng at en erfaringsbeskrivelse, uavhengig av når erfaringen fant sted, aldri er ensbetydende med selve erfaringen, men alltid vil være en transformasjon av erfaringen (van Manen, 1990, s. 54).

I og med at arbeidsprosessen fant sted for ni år siden, spiller tidsfaktoren inn som både fordel og ulempe. Den er en fordel fordi det er lettere å ha distanse til arbeidsprosessen og se den nærmest i metaperspektiv; den er en ulempe fordi deler av informasjonen ikke lenger er tilgjengelig og mye er glemt. For å komme tettere på kunstmaterialet har jeg hatt samtaler med to andre utøvere som deltok, og jeg har lest gjennom notater fra arbeidsprosessen. Samtalene bidro til å tydeliggiøre erfaringer fra arbeidsprosessen, og i notatene er mye forståelig, men mange sider er fylt med tegninger og ufullstendige setninger som det $\mathrm{i}$ dag er vanskelig å tolke.

Da jeg nå leste notatene fra arbeidsprosessen, var det svært overraskende for meg å se begrepene dialog og polyfoni nedskrevet på siden for første arbeidsdag. Jeg kan ikke huske at Bakhtin-begrepene var involvert i arbeidsprosessen fra starten av. At man kan oppdage «nye» ting gjennom å lese gamle notater, viser at det å gå tilbake i tid på dette viset også kan føre til refleksjon rundt hva som huskes og hva som glemmes, hvilket står i forbindelse med det Nyrnes (2006) skriver om det egne språket, at det er knyttet til «bits and pieces of the artist-researcher's own memoria» (s. 14).

Retrospektivt ser jeg at vi, i samsvar med polyfonibegrepet, i prøveperioden vektla at flere ytringer kunne foregå parallelt uten å stå i forbindelse med hverandre, samt å stole på at stemmene sammen utgjorde en kunstnerisk interessant improvisasjon. Det var ikke nødvendigvis klart, hverken for oss selv eller for tilskueren, hvilken stemme som var mest framtredende. Med Bakhtin forstås utøverne som selvstendige subjekter som taler med sin egen stemme. Et polyfont perspektiv innebærer dessuten at hver utøver hadde mulighet til å fremme sin kunstneriske vilje, og at dette kunne gjøres av flere utøvere parallelt. Et polyfont improvisasjonsperspektiv skiller seg på denne måten fra et mer normativt danseimprovisasjonsperspektiv, som jeg forstår mer som homofoni, der utøverne forholder seg til den ene stemmen som er mest tydelig til stede, og ytrer seg i harmoni med denne. Polyfoniens kjerne består i motsetning til dette $\mathrm{i}$ at stemmene forblir selvstendige (Bakhtin, 2003, s. 161).

\section{Hendelsen skift}

Forestillingene hadde en forhåndsbestemt omtrentlig tidsramme på 50-60 minutter, og lysdesigneren valgte avslutningsøyeblikk ved å mørklegge scenerommet helt. I tre av de i alt fire forestillingene tok to utøvere et for meg overraskende valg, som bestod i at de hver sine kvelder giorde vakre/interessante/gode/virtuose soloer som avslutning på forestillingene. Vi hadde ikke på forhånd snakket om muligheten for en slik avslutning, da denne typen «avslutningssoloer» ikke hadde forekommet i prøveperioden til tross for mange "som om»-gjennomganger, og dette markerte derfor et skift. 


\section{H. Rustad}

Én tolkning av hendelsen skift er at utøverne tok ansvar ved å rette oppmerksomheten mot forestillingens oppbygning ut fra en mer gjenkjennelig, tradisjonsbundet forestillingsstruktur ofte assosiert med koreografi, der en nydelig avslutningssolo ikke er uvanlig. De sørget for at forestillingen fikk en form for "grand finale» ved å gjennomføre handlinger som innebar «annerledes» valg, og som den åpne strukturen ga mulighet for.

En annen tolkning er at det å få publikum var noe som i seg selv inspirerte til annerledes valg. Jeg forstod allikevel de fleste valgene utøverne tok i forestillingene, som å være i resonans med gruppas prosess i prøveperioden, og også med hva jeg som leder hadde søkt å formidle som prosjektets kunstneriske vilje. Jeg tolker skift som å dreie seg om individuelt begrunnede valg mer i tråd med konvensjonelle scenekunstnormer enn med valg forankret $\mathrm{i}$ indre dialog med improvisasjonen. Individuell kunstnerisk vilje trådte på denne måten fram gjennom skift. Hendelsen viser hvordan utøveres kunstneriske vilje synliggjort gjennom valg i improvisasjonen kan stå i et dissonant forhold til lederens kunstneriske vilje. Improvisasjonen ble et møtested for konfrontasjon mellom utøverne og lederen, som talende personligheter, hvor begge parter handlet ut fra sin erfaringsbakgrunn.

I åpen improvisasjon vil imidlertid avslutningen være tilfeldig og sannsynligvis forskjellig fra gang til gang. I og med at skift skjedde tre kvelder på rad, forstod jeg dette som en villet avslutning fra enkelteutøvere, heller enn som noe som oppstod tilfeldig, basert hverken i gruppas felles arbeidsprosess eller i den gjeldende improvisasjonen. Med andre ord var det et valg basert på erfaring ervervet utenfor den inneværende arbeidsprosessen. Bakhtin hevder at alle stemmer er viktige, og kaller Dostojevskijs romanstruktur open-ended og polyfon (Stensæth, 2008, s. 184). I overført betydning er min forståelse at selv om forestillingen langt på vei var en polyfon improvisasjon, viste skift, som avslutningssolo tre dager på rad, at forestillingene slett ikke var openended. Tvert imot kunne det virke som om utøverne på forhånd hadde bestemt seg for hvordan forestillingene skulle avsluttes.

Hendelsen skift gir gjenklang i et fenomen jeg gjenkjenner fra andre improvisasjonsarbeidsprosesser. Det er ikke uvanlig at når publikum kommer på plass, liksom våkner enkelte utøvere til liv på nye måter og handler annerledes enn i prøveperioden. For eksempel kan en utøver som har forholdt seg relativt tilbaketrukket, overraskende «slå ut håret» og ta mye oppmerksomhet i forestillingen. «Sometimes this may be no more than a desire to draw attention to one's self at the expense of others: a simple case of showing off», skriver Gary Peters (2009, s. 52). Improvisasjon som scenekunst gir rom for plutselig adferdsendring hos utøverne, hvilket kan skake ved trygghet og tillit som er bygget opp utøverne imellom.

Det plutselige og risikofylte kan på samme tid forstås som positivt ved å bidra til å gjøre improvisasjon uforutsigbar og derfor mer spennende og interessant for utøvere og publikum og framstå som «assured, committed and challenging (questionraising)» (Peters, 2009, s. 54). Jeg forsøker her å argumentere for at det er mulig å skille mellom positivt ladede uforutsigbare valg, som står i et indre dialogisk forhold 
til improvisasjonen selv, og negativt ladede uforutsigbare valg, som står i et dissonant, ikke-dialogisk forhold til gjeldende improvisasjon.

En hovedintensjon i arbeidsprosessen var i størst mulig grad å la ting få være som de var, å la det som oppstod, heteroglott, få ta plass, og ikke på noen måte planlegge hva som skulle skje. I tillegg var det å lytte til improvisasjonens selv, og derigjennom følge improvisasjonens logikk, viktig. Fordi jeg forstår hendelsen skift som planlagt, utgjorde den et brudd med prosjektets intensjon og dermed også med prosjektets kunstneriske vilje.

Improvisasjon innebærer som vist risiko for den kunstneriske lederen fordi lederen gjennom å velge improvisasjon som scenekunstuttrykk gir fra seg makten til å bestemme hva som skal skje i forestillingene. I forestillingen tok hver utøver valg og ytret seg fortløpende som selvstendig subjekt. I polyfon improvisasjon blir utøverens «jeg» derfor synlig på en helt annen måte enn i en tradisjonell forståelse av koreografi, hvor valg og ansvar ligger hos koreografen som kunstneren som ytrer seg gjennom utøverne. I improvisasjon kan ytringer vanskelig skilles fra stemmene som ytrer seg; en polyfon gruppeimprovisasjon vil derfor synliggjøre flere utøveres kunstneriske viljer, slik det skjedde med hendelsen skift.

\section{Hendelsen bemerkning}

Det er mulig at de utøverne jeg ikke hadde jobbet med tidligere, forventet en annerledes og sterkere ledelse. Det som ligger til grunn for denne antagelsen, er at jeg etter at vi hadde kommet inn i teatret, kom til å overhøre en bemerkning fra en annen utøver som jeg der og da forstod som om utøveren mente at jeg som leder hadde dårlig selvtillit. Videre tolket jeg dette til at vedkommende mente jeg utviste dårlig lederskap. I ettertid har jeg reflektert over hvordan bemerkningen gjorde inntrykk på meg. Forstod jeg den rett, og som kritikk mot meg som leder, og var jeg enig i at jeg utviste for lite og/eller for utydelig lederskap? Det å overhøre bemerkningen var ubehagelig. Innebar ubehaget at det å være i rollene som både utøver og leder var en for sårbar eller for kompleks situasjon?

Hendelsen bemerkning peker på nødvendigheten av å tydeliggjøre hva en slik dobbeltrolle som leder og utøver innebærer for den som har dobbeltrollen, og for de andre utøverne. Dobbeltrollen som leder og utøver er relativt vanlig i det norske dansekunstfeltet, men lite problematisert.

\section{Ledelse, flat struktur og ikke-hierarki?}

Ideen til forestillingen var min. Jeg stod som kunstnerisk og administrativt ansvarlig, sørget for finansiering, inviterte de andre inn og ledet prosessen. Til tross for dette var min intensjon å få til en prosess med flat struktur og demokratiske verdier; alle skulle være medbestemmende, ingen dominere, alle komme til orde, og vi skulle utvikle prosjektet sammen. Det å lede prosjektet, som en relativt lite styrt prosess, medførte som vist vanskeligheter. Hvordan skulle jeg få de andre til å forstå prosjektets 


\section{H. Rustad}

kunstneriske vilje, som handlet om min forståelse av prosjektet som polyfont, uten å legge for sterke føringer? Relatert til dette skriver Donna Ladkin og Steven Taylor (2010) om hvordan både kunst og lederskap krever evnen til å kunne jobbe i motsetningsfylte kontekster (s. 237), da mange kunstarbeidsprosesser innebærer motsetninger og paradoks (Ladkin \& Taylor, 2010, s. 238).

Retrospektivt ser jeg min måte å lede forestillingen i samsvar med at jeg forstår nærmest som premiss - det å improvisere flere sammen som å kreve åpenhet og aksept for hverandre og hverandres valg, og at utøverne er likestilt og står i et ikkehierarkisk forhold til hverandre. Som leder var min intensjon at forestillingen skulle forstås som en polyfon kontekst der stemmene sammen var skapende, og ikke som en forestilling hvor én stemme var framtredende. Dette kan forstås mer som et horisontalt, samarbeidende lederskap, hvor vekten ligger mer på funksjon og mindre på person (Furu, 2013, s. 213). Dette innebar også at den som hadde mest kompetanse, for eksempel innenfor musikk, fungerte som musikalsk leder. Som i en god samtale så jeg for meg at stemmene skulle være likeverdige, men også gjerne respektløst «snakke» i munnen på hverandre. Det var først med hendelsen skift, og forestillingsavslutninger som framstod mer som monologer enn som polyfoni, at jeg kjente at noe skurret.

Med skift oppstod et dilemma - skulle jeg snakke med de andre og dermed forhindre at skift skjedde også i siste forestilling, og ta sjansen på at dette kunne føre til mistillit og vanskeligere, kanskje mindre dialogiske, improvisasjonsforhold, eller skulle jeg la det være? Jeg valgte å ta situasjonen opp med de andre, og - sannsynligvis som en følge av dette - fikk siste forestilling en annen avslutning. Å ha ansvar for en improvisasjonsforestilling innebærer å gi fra seg kontroll, men det er også nødvendig å opprettholde dialog og kunne kommunisere dersom noe uforutsett, ikke ønsket, skjer. Ved at jeg erkjente, og gjorde kjent, at monologisk avslutning ikke var i tråd hverken med min forståelse av improvisasjon eller med det jeg forstod at vi som gruppe hadde jobbet med i arbeidsprosessen, trådte min kunstneriske vilje tydeligere fram for meg selv og de andre.

Å lede et scenekunstprosjekt er å inneha en maktposisjon. Hendelsen skift skjøv meg på denne måten over i en mer autoritær lederstil. Det er et paradoks at jeg, som hadde som intensjon å jobbe med åpen improvisasjon og flat ledelse med utøverne som selvstendige stemmer i forestillingene, grep inn da ytringene ikke var i samsvar med min kunstneriske vilje.

Arbeidsprosessen med forestillingen kan knyttes til det Bakhtin sier om at ordet bærer med seg stemmer fra tidligere brukere, og kan forstås som møtested og som konfrontasjon (Igland \& Dysthe, 2008, s. 111) mellom på den ene siden utøvernes erfaring fra det å arbeide i koreograferte forestillinger med sterkt lederskap og på den andre siden forestillingen med polyfon improvisasjon som kunstuttrykk, hvor jeg i dobbeltrollen som leder og utøver ønsket å være mest mulig sidestilt med utøverne og derfor la opp til en ikke-autoritær lederstil.

I tråd med selvstudieforskning forhandler jeg mening mellom min biografi og kunstmaterialet, og jeg forstår mitt ønske om å gi utøverne, på lik linje med meg selv som 
prosjektets leder, autoritet som et resultat av min tilhørighet til kontaktimprovisasjon. Steve Paxton, som initierte kontaktimprovisasjon, uttaler seg tydelig negativt til lederskap i improvisasjonssammenheng og snakker om improvisasjon som antihierarkisk (Paxton i Paxton \& Mazzaglia, 2013, s. 274). Det at jeg ønsket å ta en ikkehierarkisk lederrolle, kan i tillegg forstås ut fra erfaringer jeg har gjort som utøver i både improvisasjons- og koreografisammenheng hvor lederen/koreografen har hatt en autoritær lederstil jeg har opplevd som negativ.

I løpet av arbeidsprosessen utviklet jeg større bevissthet rundt betydningen av å se prøveperiode og forestillinger som helhet. Å formidle innsikt som kom til underveis, stilte krav til meg som leder, og i dobbeltrollen som leder og utøver forstod jeg det som viktig å kommunisere ikke-autoritært og å underkommunisere lederrollen. Det å være både leder som viste kunstnerisk vilje og utøver på linje med de andre, innebar imidlertid konflikt. I tråd med Ladkin og Taylor (2010), som skriver om hvordan "such 'backward reflexitivty' [...] could be an important source of leadership sensemaking» (s. 238), måtte jeg erkjenne for meg selv at jeg, selv om jeg hadde intensjoner om flat struktur og polyfon improvisasjon, ønsket å gjennomføre min kunstneriske vilje, som ideer om hva og hvordan prosjektet skulle være, også dersom det gikk på bekostning av andres kunstneriske vilje.

\section{Sameksistens, interaksjon, kaos og konfrontasjon}

Bakhtin skriver at den grunnleggende kategorien i Dostojevskijs kunstneriske visjon ikke var tilblivelsen, men sameksistens og interaksjon (Bakhtin, 2003, s. 171). Stensæth hevder at improvisasjon i konteksten musikkterapi skaper en egen type aktiv sammenhet og mestring av dialogiske ferdigheter (Stensæth, 2008, s. 258), og jeg argumenter for at dette utvikles nettopp $\mathrm{i}$ arbeidsprosesser hvor man bevisstgjøres gjennom improvisasjon og refleksjon som samtale om improvisasjon. Stensæth hevder at handlende utøvere i improvisasjonen har en dialogisk innstilling. Slik jeg ser det, er dette ytterligere en poengtering av nødvendigheten av at utøverne er åpne for hverandre og hverandres ytringer, men også for den sosiale konteksten arbeidsprosessen rammer inn, som favner tiden man tilbringer sammen i tilknytning til kunstprosjektet, hvor relasjoner utøverne imellom kan ha direkte innvirkning på hvilke valg som tas i selve improvisasjonen.

I en polyfon improvisasjon vil stemmene ha lik rett til å ytre seg, gjerne samtidig, og ingen har kontroll over helheten. Det er med andre ord rom for kaos og uenighet, og konfrontasjoner mellom personer kan finne sted også innenfor rammen av selve improvisasjonen. Om dette skriver Peters følgende:

For all of the talk of dialogue, we witness here in the "pushing and pulling» of improvisation $[\ldots .$.$] of the collective and the singular, the "yes» and «no» of the work played$ out in full view of the audience. (Peters, 2009, s. 53)

Det at personlige uoverensstemmelser mellom utøvere kan spille inn, og at det også kan handle om makt og hierarki utøvere imellom $\mathrm{i}$ improvisasjon, gripes sjelden fatt $\mathrm{i}$. 


\section{Dansekunstfeltets konvensjoner og normer}

Dansekunstfeltets konvensjoner og normer kan ha spilt negativt inn i arbeidsprosessen. I koreograferte samtidsdansforestillinger har normen tidligere vært at koreografen tar de fleste avgjørelser, og dette har vært hva utøverne har forventet. Andrej Lepecki er kritisk og setter normen på spissen når han skriver følgende:

Choreography demands a yielding to commanding voices of masters (living and dead), it demands submitting body and desire to disciplining regimes (anatomical, dietary, gender, racial), all for the perfect fulfillment of a transcendental and preordained set of steps, postures, and gestures that nevertheless must appear «spontaneous». (Lepecki 2006, s. 9)

I sterk kontrast til dette sitatet involverer Bakhtin dialog som intertekstualitet mellom meninger, og i polyfoni skapes kompleksitet som gjør det vanskelig å si hvem som snakker, og hvem som mener (Stensæth, 2008, s. 187), hvilket i en gruppeimprovisasjonsforestilling kan innebære at flere personers kunstneriske vilje gjennomføres. Polyfoni bryter med den tidligere koreografinormen, der kunstnerisk vilje lå hos én person, som én stemme.

Normen har de siste årene gjentatte ganger vært diskutert (Holte, 2016; Rustad, 2017; Sparre, 2014; Østern, 2016). I dag anerkjenner de fleste koreografer danserne som medskapende, hvilket kommer til uttrykk i forestillingsinformasjon, men forestillingsarbeid innebærer allikevel vanligvis hierarkiske beslutningsprosesser hvor koreografen eller den kunstneriske lederen er på toppen.

\section{Oppsummerende drøfting}

Problemstillingen På hvilke måter kommer kunstnerisk vilje til syne $i$ en arbeidsprosess med danseimprovisasjon som scenekunst? har jeg besvart gjennom å undersøke forestillingen som arbeidsprosess og kontekstuell kunstnerisk praksis. Bakhtin har bidratt til å tydeliggjøre hvordan kunstnerisk vilje $\mathrm{i}$ et polyfont improvisasjonsprosjekt først og fremst handler om å bringe utøverne sammen som individuelle viljer (Bakhtin, 2003, s. 161). Ved å anvende Bakhtin har jeg skrevet fram komplekse sider av kunstmaterialet og synliggjort hvordan både jeg, i lederrollen, og de andre utøverne har gjennomført ideer som kunstnerisk vilje i arbeidsprosessen.

Flere forhold bringes fram i lyset når man forsker med og på kunstmaterialet hentet fra forestillingen. Hendelsen skift får fram at det er et viktig spørsmål hvorvidt utøverne som bringes sammen i arbeidsprosessen, har tillit til polyfon improvisasjon som scenekunstuttrykk. Kunstmaterialet belyser motsetninger og meningsbrytninger i arbeidsprosessen, som dissonans mellom stemmer og friksjon mellom min forforståelse av hvordan jeg ønsket å være som leder, og det som utspilte seg underveis. Dissonansen skyldtes både at utøverne og jeg som leder hadde ulik forforståelse av improvisasjon og av prosjektets intensjon, og at jeg i dobbeltrollen som leder-utøver ikke klarte å formidle prosjektets kunstneriske vilje tydelig nok. Min tolkning er at en av hovedårsakene til dissonansen var dobbeltrollen leder-utøver og forholdet mellom 
min lederstil og min historie som kontaktimprovisasjonsutøver. Kunstmaterialet synliggjør spenninger mellom meg som leder-utøver og de andre utøverne og tydeliggiør hvordan ytringer kan forstås som brudd med det polyfone improvisasjonsperspektivet som ellers preget arbeidsprosessen.

Artikkelen handler også om hvordan arbeidsprosesser kan romme konfliktfylt sameksistens mellom ledere og utøvere, samt betydningen av at ledere evner å være i dialog med utøvere om hva prosjektet består i og å kommunisere dersom/når ny innsikt kommer til. Ledere står i en kontinuerlig prosess som handler om å skape mening og må ha evne til å reflektere og lære fra prosessen: «A leader, then, can be viewed as 'a seeker, a questioner and crafter of meaning'" (Furu, 2013, s. 220). Det skapes mening og progresjon i artikkelen ved at jeg har et selvkritisk blikk på meg selv som leder, setter spørsmålstegn ved dansekunstfeltets konvensjoner og retter oppmerksomhet mot dobbeltrollen som leder og utøver.

Å skrive artikkelen innebar å designe en metodologi som muliggjorde retrospektiv forskning på kunstpraksis. Designet bygger på Nyrnes' (2006) metodologiske forslag, som er bevegelse fram og tilbake mellom kunstmaterialet, teorien og det egne språket, i tillegg til anvendelse av et selvstudieteoretisk perspektiv (Bullough \& Pinnegar, 2001). Jeg har skrevet fram mening ved å se sammenheng mellom kunstmaterialet og min erfaringsbakgrunn. Deler av kunstmaterialet kan betegnes som konfliktfylt, hvor spenninger mellom min relasjon til praksis og til utøverne jeg delte praksis med, har betydning.

Gjennom forskning med kunst på kunst bidrar artikkelen med kunnskap om danseimprovisasjon som scenekunstpraksis, og jeg har forholdt meg til Rouhiainen (2008, s. 56) når hun skriver om et dialogisk forhold mellom kunstnerisk praksis og kunstnerens egne kritiske kommentarer i form av samtale eller skrevet tekst, der nettopp artikulasjon som samtale eller tekst er nødvendig for at andre skal kunne dra nytte av kunnskapen. Svært mange arbeidsprosesser i scenekunstfeltet utgjøres av enkeltstående prosjekter som spilles relativt få ganger. Ved hvert av disse skapes kunst og utvikles kunnskap om kunst, og det er problematisk at kunnskapen i mange tilfeller nærmest går i oppløsning ved prosjektets slutt. Ledere og utøvere går hver til sitt, og til tross for at enkeltindivider tilegner seg ny kunnskap, er det ikke slik at denne blir gjort tilgjengelig for flere. Til dette trenger vi forskning på kunst med kunst og relevante kanaler for kunstforskningsformidling.

Jeg, som én stemme, har skrevet ut fra mine erfaringer med forestillingen, og det er på ingen måte sikkert at de andre utøverne som deltok, enten kan si seg enig i beskrivelsen i Arbeidsprosess-skisse eller huske hendelsene skift og bemerkning. Jeg vil allikevel argumentere for at artikkelen som «knowledge from an artist's point of view that is retrived through practice and a reflection and is articulated artistically and verbally» (Rouhiainen, 2008, s. 51) er et relevant kunnskapsbidrag både når det gjelder danseimprovisasjon som scenekunst, og når det gjelder ledelse av slike prosjekter.

Et forslag til videre forskning med og på danseimprovisasjon som scenekunstpraksis er å gjennomføre et scenekunstprosjekt hvor det på forhånd er klart at det dreier 


\section{H. Rustad}

seg om nettopp kunstforskning, hva som skal forskes på og med hvilke metoder, hvor flere stemmer som forskere og utøvere sammen gjennomgående er involvert.

Feg retter en varm takk til utøverne i forestillingen, som gjorde arbeidsprosessen, og dermed også det å skrive om arbeidsprosessen, mulig.

\section{Forfatteromtale:}

Hilde Rustad (ph.d.) er danseforsker, dansekunstner og -pedagog og er ansatt som postdoktor ved Norges idrettshøgskole. Hennes doktoravhandling Dans etter egen pipe? handler om improvisasjon, danseimprovisasjon og kontaktimprovisasjon. Rustad har en Nordic Master of Dance Studies (NO-MA-DS) fra NTNU. Hun er utdannet danser og koreograf fra Kunsthøgskolen i Amsterdam, avdeling School for New Dance Development (SNDO). Rustad er del av den nordisk-russiske gruppa «After Contemporary» og styremedlem i Nordisk Forum for Danseforskning (NOFOD).

\section{Litteratur}

Bakhtin, M. (1981). The dialogic imagination. Austin, TX: University of Texas Press.

Bakhtin, M. (2003). Latter og dialog. Oslo: Cappelen Akademisk Forlag.

Borgdorff, H. (2006). The debate on research in the arts. Sensuous knowledge, 2. Bergen: Kunsthøgskolen i Bergen. Hentet 12.11.2017 fra http://upers.kuleuven.be/sites/upers.kuleuven.be/files/page/files/2007_1_2.pdf

Bullough, R.V., Jr. \& Pinnegar, S. (2001). Guidelines for quality autobiographical forms of self-study research. Educational Researcher, 30(3), 13-21.

Børtnes, J. (2008). Bakhtin, dialogen og den andre. I O. Dysthe (Red.), Dialog, samspel og lcering (s. 91-106). Oslo: Abstrakt forlag.

Furu, P. (2013). The art of collaborative leadership in jazz bands. I J. Caust (Red.), Arts leadership: International case studies (s. 211-223). Prahran, Australia: Tilde University Press.

Holte, S.S. (2016). Koreografens død - spira til ei ny forståing i koreografi. I S.Ø. Svendal (Red.), Bevegelser: Norsk dansekunst i 20 år (s. 245-268). Leikanger: Skald.

Hovik, L. (2012). Mamma danser: teater for de minste som kunstnerisk forskning. Information: Nordic fournal of Art and Research, 1(2), 94-111.

Igland, M.A. \& Dysthe, O. (2008). Mikhail Bakhtin og sosiokulturell teori. I O. Dysthe (Red.), Dialog, samspel og lering (s. 107-127). Oslo: Abstrakt forlag.

Ladkin, D. \& Taylor S.S. (2010). Leadership as art: Variations on a theme. Leadership, 6(3), 235-241.

Lepecki, A. (2006). Exhausting dance: Performance of the politics of movement. London: Routledge.

Mørch, A.J. (2003). I M. Bakhtin, A.J. Mørch (oversetter), Latter og dialog (s. 5-28). Oslo: Cappelen Akademisk Forlag.

Nyrnes, A. (2006). Lighting from the side: Rhetoric and artistic research. Bergen: Kunsthøgskolen i Bergen.

Paxton, S. \& Mazzaglia, R. (2013). Thoughts on contact improvisation. Danza e ricerca, 4, 264-280. https://doi. org/10.6092/issn.2036-1599/4204

Peters, G. (2009). The philosophy of improvisation. Chicago: The University of Chicago Press.

Rouhiainen, L. (2008). Artistic research and collaboration. Nordic Theatre Studies, 20, 51-60.

Rustad, H. (2010a). Improvisasjon - kreativ nyskapning eller gjenbruk. I K. Steinsholt \& K.P. Gurholt (Red.), Aktive liv: Idrettspedagogiske perspektiver på kropp, bevegelse og dannelse (s. 121-142). Trondheim: Tapir akademisk forlag.

Rustad, H. (2010b). Danseimprovisasjon som forestilling i lys av Bakhtin og Gadamer. I S. Pape (Red.), Norsk danseforskning (s. 61-79). Trondheim: Tapir akademisk forlag.

Rustad, H. (2013). Dans etter egen pipe? En analyse av danseimprovisasjon og kontaktimprovisasjon som tradisjon, fortolkning og levd erfaring. (Doktoravhandling). Oslo: Norges idrettshøgskole.

Rustad, H. (2017). Livets dans og danserens liv: En drøfting av forståelser av danseralder. På spissen, 3(1), 1-21. DOI: http://ps.noda.no/index.php/ps/article/view/12\%22\%3eLIVETS (Hentet 17.11.2017).

Sparre,V. (2014). Trenger vi koreografer? Hentet 12.10.2017 fra http://www.scenekunst.no/sak/trenger-vi-koreografer/

Stensæth, K. (2008). Musical answerability: A theory on the relationship between music therapy improvisation and the phenomenon of action. (Doktoravhandling). Oslo: Norges musikkhøgskole. 
Stensæth, K. (2017). Responsiveness in music therapy improvisation - a perspective inspired by Mikhail Bakhtin. Dallas: Barcelona Publishers.

Thune, H. (2012). Mikhail Bakhtin's aesthetic object. (Doktoravhandling). Stavanger: Universitetet i Stavanger. van Manen, M. (1990). Researching lived experience. Albany, NY: State University of New York Press.

Østern, T.P. (2016). Å la kroppslig kunnskaping flyte fram og tilbake i en kunstnerisk-koreografisk veiledningsprosess. I A-L. Østern \& G. Engvik (red.), Veiledningspraksiser i bevegelse: Skole, utdanning og kulturliv (s. 119-141). Bergen: Fagbokforlaget.

\section{Kompanier og prosjekter referert til i artikkelen}

Prosjekt Impro

Impro Ensemble

After contemporary. Hentet 03.02.2018. http://aftercontemporary.net/ 